
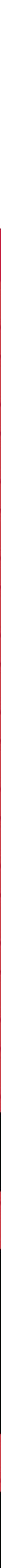
Directeur de LA PUBlication / PUblicAtion DIRECTOR : Bruno David,

Président du Muséum national d'Histoire naturelle

RÉDACTEUR EN CHEF / EDITOR-IN-CHIEF : Didier Merle

ASSISTANT DE RÉDACTION / ASSISTANT EDITOR: Emmanuel Côtez (geodiv@mnhn.fr)

Mise EN PAGE / PAGE LAYOUT: Emmanuel Côtez

COMITÉ SCIENTIFIQUE / SCIENTIFIC BOARD:

Christine Argot (Muséum national d'Histoire naturelle, Paris)

Beatrix Azanza (Museo Nacional de Ciencias Naturales, Madrid)

Raymond L. Bernor (Howard University, Washington DC)

Alain Blieck (chercheur CNRS retraité, Haubourdin)

Henning Blom (Uppsala University)

Jean Broutin (Sorbonne Université, Paris, retraité)

Gaël Clément (Muséum national d'Histoire naturelle, Paris)

Ted Daeschler (Academy of Natural Sciences, Philadelphie)

Bruno David (Muséum national d'Histoire naturelle, Paris)

Gregory D. Edgecombe (The Natural History Museum, Londres)

Ursula Göhlich (Natural History Museum Vienna)

Jin Meng (American Museum of Natural History, New York)

Brigitte Meyer-Berthaud (CIRAD, Montpellier)

Zhu Min (Chinese Academy of Sciences, Pékin)

Isabelle Rouget (Muséum national d'Histoire naturelle, Paris)

Sevket Sen (Muséum national d'Histoire naturelle, Paris, retraité)

Stanislav Štamberg (Museum of Eastern Bohemia, Hradec Králové)

Paul Taylor (The Natural History Museum, Londres, retraité)

COUVERTURE / COVER:

Réalisée à partir des Figures de l'article/Made from the Figures of the article.

Geodiversitas est indexé dans / Geodiversitas is indexed in:

- Science Citation Index Expanded (SciSearch $\left.{ }^{\circledR}\right)$

- ISI Alerting Services ${ }^{\circledR}$

- Current Contents ${ }^{\circledR}$ / Physical, Chemical, and Earth Sciences ${ }^{\circledR}$

- Scopus ${ }^{\circledR}$

Geodiversitas est distribué en version électronique par / Geodiversitas is distributed electronically by:

- BioOne ${ }^{\circledR}$ (http://www.bioone.org)

Les articles ainsi que les nouveautés nomenclaturales publiés dans Geodiversitas sont référencés par / Articles and nomenclatural novelties published in Geodiversitas are referenced by:

- ZooBank ${ }^{\circledR}$ (http://zoobank.org)

Geodiversitas est une revue en flux continu publiée par les Publications scientifiques du Muséum, Paris Geodiversitas is a fast track journal published by the Museum Science Press, Paris

Les Publications scientifiques du Muséum publient aussi / The Museum Science Press also publish: Adansonia, Zoosystema, Anthropozoologica, European Journal of Taxonomy, Naturae, Cryptogamie sous-sections Algologie, Bryologie, Mycologie, Comptes Rendus Palevol

Diffusion - Publications scientifiques Muséum national d'Histoire naturelle

CP $41-57$ rue Cuvier F-75231 Paris cedex 05 (France)

Tél. : 33 (0)14079 4805 / Fax: 33 (0)14079 3840

diff.pub@mnhn.fr / http://sciencepress.mnhn.fr

(C) Publications scientifiques du Muséum national d'Histoire naturelle, Paris, 2021

ISSN (imprimé / print): 1280-9659/ ISSN (électronique / electronic): 1638-9395 


\section{A Messinian (latest Miocene) occurrence for Albanerpeton Estes \& Hoffstetter, 1976 (Lissamphibia: Albanerpetontidae) at Moncucco Torinese, Piedmont Basin, northwestern Italy, and a review of the European Cenozoic record for albanerpetontids}

James D. GARDNER
Royal Tyrrell Museum of Palaeontology, Box 7500, Drumheller, Alberta, TOJ 0Y0 (Canada)
james.gardner@gov.ab.ca

Andrea VILLA

Bayerische Staatssammlung für Paläontologie und Geologie, Richard-Wagner-Straße 10, 80333 München (Germany) and Dipartimento di Scienze della Terra, Università degli Studi di Torino, Via Valperga Caluso 35, 10125 Torino (Italy) and Institut Català de Paleontologia Miquel Crusafont, Universitat Autònoma de Barcelona, Edifci ICTA-ICP, Carrer de les Columnes s/n, Campus de la UAB, 08193, Cerdanyola del Vallès, Barcelona (Spain) a.villa@unito.it

Simone COLOMBERO Dipartimento di Scienze della Terra, Università degli Studi di Torino, Via Valperga Caluso 35, 10125 Torino (Italy) simone.colombero@unito.it

Márton VENCZEL Tării Crişurilor Museum, Armatei Române 1/A, RO-410087 Oradea (Romania) mvenczel@gmail.com

Massimo DELFINO

Dipartimento di Scienze della Terra, Università degli Studi di Torino, Via Valperga Caluso 35, 10125 Torino (Italy) and Universitat Autònoma de Barcelona, Edifici ICTA-ICP, Carrer de les Columnes s/n, Campus de la UAB, E-08193 Cerdanyola del Vallès, Barcelona (Spain) massimo.delfino@unito.it

Submitted on 11 October 2019 | accepted on 27 February 2020 | published on 1 July 2021

urn:Isid:zoobank.org:pub:5EDF5351-1F3B-43A7-B88C-C72E2A511176

Gardner J. D., Villa A., Colombero S., Venczel M. \& Delfino M. 2021. - A Messinian (latest Miocene) occurrence for Albanerpeton Estes \& Hoffstetter, 1976 (Lissamphibia: Albanerpetontidae) at Moncucco Torinese, Piedmont Basin, northwestern Italy, and a review of the European Cenozoic record for albanerpetontids, in Steyer J.-S., Augé M. L. \& Métais G. (eds), Memorial Jean-Claude Rage: A life of paleo-herpetologist. Geodiversitas 43 (14): $391-404$. https://doi.org/10.5252/geodiversitas2021v43a14. http://geodiversitas.com/43/14

KEY WORDS Albanerpetontidae,

Albanerpeton,

Moncucco Torinese,

Piedmont Basin,

Miocene,

Messinian.

\section{ABSTRACT}

Albanerpetontids are an extinct clade of superficially salamander-like lissamphibians that range from the Middle Jurassic (Bathonian)-Early Pleistocene and have a primarily Laurasian distribution. The best Cenozoic record for the clade is in Europe, where two species in the type genus Albanerpeton Estes \& Hoffstetter, 1976 occur in over 40 localities of early Oligocene-Early Pleistocene age in Austria, Czech Republic, France, Germany, Hungary, Italy, and Serbia. From the post-evaporitic Messinian (5.41-5.33 Ma or latest Miocene) succession at Moncucco Torinese, in the Piedmont Basin, northwestern Italy, here 
MOTS CLÉS Albanerpetontidae, Albanerpeton, Italie,

Moncucco Torinese, bassin du Piémont, Miocène, Messinien. we describe isolated albanerpetontid jaws and vertebrae referable to $A$. pannonicum Venczel \& Gardner, 2005. This Italian occurrence extends the temporal record for $A$. pannonicum from the Early Pleistocene and Pliocene back into the latest Miocene and it narrows the temporal gap between that species and its European congener, A. inexpectatum Estes \& Hoffstetter, 1976 (early Oligocene-late Miocene).

\section{RÉSUMÉ}

Occurrence messinienne (Miocène supérieur) d'Albanerpeton Estes \& Hoffstetter, 1976 (Lissamphibia: Albanerpetontidae) à Moncucco Torinese, Bassin du Piémont, Italie du nord-ouest, et révision du registre cénozoïque des albanerpetontidés d'Europe.

Les albanerpetontidés représentent un clade éteint de lissamphibiens ressemblant superficiellement à des salamandres, dont l'aire de répartition s'étend du Jurassique moyen (Bathonien) au Pléistocène inférieur, et dont la distribution est principalement laurasiatique. Le meilleur registre cénozoïque pour ce clade se trouve en Europe, où deux espèces du genre-type Albanerpeton Estes \& Hoffstetter, 1976 sont présentes dans plus de 40 localités de l'Oligocène inférieur-Pléistocène inférieur d'Autriche, Tchéquie, France, Allemagne, Hongrie, Italie et Serbie. Nous décrivons ici des mâchoires et des vertèbres isolées d'albanerpetontidés pouvant être attribuées à $A$. pannonicum Venczel \& Gardner, 2005, provenant de la succession post-évaporitique du Messinien (5,41-5,33 Ma ou Miocène terminal) à Moncucco Torinese, dans le bassin du Piémont, au nord-ouest de l'Italie. Cette occurrence italienne étend l'enregistrement stratigraphique d'A. pannonicum du Pléistocène inférieur et du Pliocène jusqu'au Miocène supérieur, et réduit l'écart temporel entre cette espèce et son congénère européen, A. inexpectatum Estes \& Hoffstetter, 1976 (Oligocène inférieur-Miocène supérieur).

\section{INTRODUCTION}

Albanerpetontidae Fox \& Naylor, 1982 are a clade of small sized (total body length less than $15 \mathrm{~cm}$ ), salamander-like amphibians with a temporal range extending from the Middle Jurassic (Bathonian) to Early Pleistocene and a geographic distribution encompassing Europe, Asia, North Africa, and North America (e.g., see reviews by Gardner \& Böhme 2008; Gardner \& Rage 2016; Evans \& Matsumoto 2018). Currently 14 named species in six genera are recognized (Estes \& Hoffstetter 1976; Estes 1981; Fox \& Naylor 1982; McGowan \& Evans 1995; Gardner 1999a, b, c, 2000a, b; McGowan 2002; Gardner et al. 2003; Venczel \& Gardner 2005; Sweetman \& Gardner 2013; Matsumoto \& Evans 2018; Daza et al. 2020). Although over a half dozen articulated and associated skeletons have been recovered from the Cretaceous of Europe and eastern Asia (Costa 1864; McGowan \& Evans 1995; McGowan 2002; Matsumoto \& Evans 2018; Daza et al. 2020), the albanerpetontid fossil record overwhelmingly consists of isolated and occasional articulated bones, especially the distinctive jaws, skull roofing bones, and vertebrae (e.g., Estes \& Hoffstetter 1976; Estes 1981; Fox \& Naylor 1982; Evans \& Milner 1994; McGowan 1996; McGowan \& Ensom 1997; Gardner 1999a, b, c, 2000a, b, 2002; Wiechmann 2003; Venczel \& Gardner 2005; Skutschas 2007; Gardner \& Böhme 2008; Sweetman \& Gardner 2013; Szentesi et al. 2013). Judging from the number of bones recovered at some localities and rock units (e.g., Campanian of southern Alberta, Canada: Brinkman et al. 2004; Miocene of La Grive-Saint- Alban, France: Estes \& Hoffstetter 1976; Pliocene of Csarnóta 2, Hungary: Venczel \& Gardner 2005), albanerpetontids were abundant in certain paleoecological settings.
The Italian record for albanerpetontids is limited to just three occurrences (Fig. 1). The holotype skeleton of Celtedens megacephalus (Costa, 1864) from the Lower Cretaceous (lower Albian) Pietraroja locality, near Naples in southwestern Italy, is the earliest published report of a fossil eventually recognized as being an albanerpetontid (see historical summaries by Estes 1981; McGowan 2002; Gardner \& Böhme 2008). The geologically youngest global record (Early Pleistocene) for Albanerpetontidae is founded on isolated skull bones and vertebrae referred to Albanerpeton pannonicum Venczel \& Gardner, 2005 from Rivoli Veronese, in northeastern Italy (Delfino \& Sala 2007). The third Italian occurrence for albanerpetontids consists of isolated jaws and rare vertebrae from the uppermost Miocene locality of Moncucco Torinese in the northwestern part of the country. The presence of albanerpetontids at Moncucco Torinese was first mentioned by Colombero et al. (2014a) in a conference abstract. Subsequently, the material was reported in a preliminary manner by Colombero et al. (2017) within their larger review of the Moncucco Torinese fauna. Here we describe the Moncucco Torinese albanerpetontid material and assign it to A. pannonicum, an identification that extends the temporal range for this geologically youngest albanerpetontid species back into the latest Miocene.

\section{THE MONCUCCO TORINESE LOCALITY}

Considering that the regional setting, geology, and paleontology of the Moncucco Torinese locality have been exhaustively detailed in earlier publications (e.g., Angelone et al. 2011; Colombero et al. 2014c; Harzhauser et al. 2015; Lozar et al. 


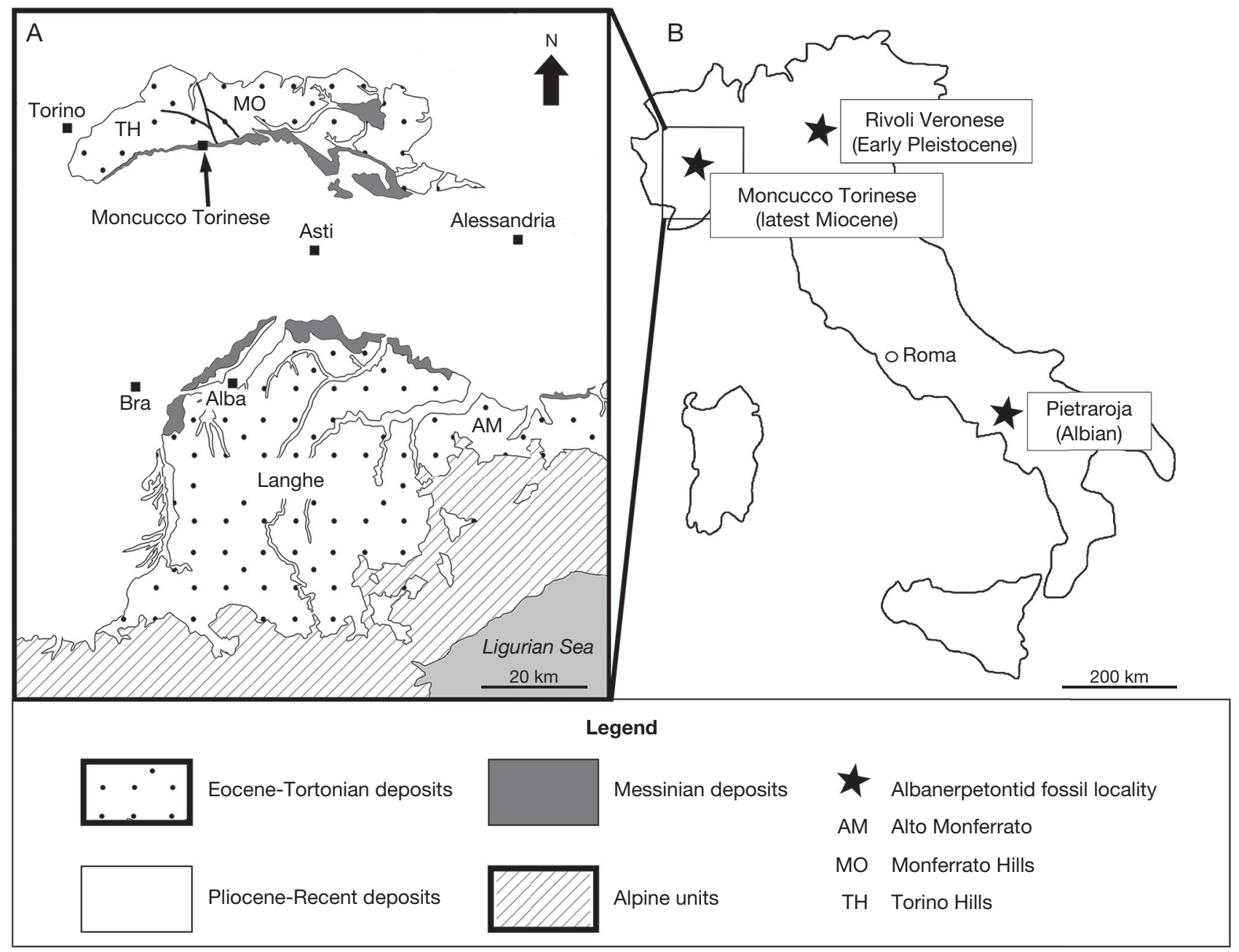

FIG. 1. - Location and setting of the uppermost Miocene Moncucco Torinese fossil locality: detail map (A) of northwestern Italy showing geographic setting and regional geology of the Tertiary age Piedmont Basin and regional map (B) showing locations of the three known albanerpetontid localities within Italy. Maps modified from Lozar et al. (2015: fig. 4) and Colombero et al. (2015: fig. 1).

2015; Colombero et al. 2017), here we present only an overview of the locality. Moncucco Torinese is located about 25 $\mathrm{km}$ east-southeast of Torino, within a commercial gypsum quarry along the southern slope of the Torino Hills, in the northern part of the Tertiary age Piedmont Basin (Fig. 1). The quarry exposes a complex succession of pre-evaporitic Messinian through to lower Pliocene sediments; fossils occur near the top of the sequence, within the post-evaporitic Cassano Spinola Conglomerates (Fig. 2). This unit consists of clay, silt, sand, and gravel and is reliably dated as latest Messinian or late Turolian (MN 13) on the basis of its ostracod, mollusc, and mammal assemblages, the presence of the Miocene-Pliocene boundary at the top of the unit, and regional stratigraphic correlations (e.g., Angelone et al. 2011; Colombero et al. 2014b, c; Harzhauser et al. 2015; Colombero et al. 2017). Within the quarry, a $3.5 \mathrm{~m}$ interval in the middle part of the Cassano Spinola Conglomerates contains abundant shells of ostracods, snails, and clams, rare otoliths of bony fish, and numerous bones, teeth, and scutes of small and medium sized tetrapods that collectively pertain to over 150 species (Colombero et al. 2017 and references therein). Nine layers are recognized, numbered from bottomto-top as M1 through M9, with vertebrate fossils - including the albanerpetontid bones reported here - restricted to four layers: M3-5 and M7 (Angelone et al. 2011; Colombero et al. 2017). The absolute age of the vertebrate fossil-bearing interval can be constrained further to 5.41-5.33 Ma based on a rich brackish water ostracod assemblage in the underlying layer M1 that correlates with the Loxocorniculina djafarovi assemblage, which is dated at $5.40 \mathrm{Ma}$ (Grossi et al. 2011), and the $5.33 \mathrm{Ma}$ age assigned to the Miocene-Pliocene (Messinian-Zanclean) boundary (e.g., Ogg et al. 2016), which is demarcated by the black arenitic layer at the top of the Cassano Spinola Conglomerates (Fig. 2). Sedimentological and faunal evidence indicate that the vertebrate fossil-bearing interval at Moncucco Torinese samples a mosaic of terrestrial and largely ephemeral freshwater environments that flourished under subtropical and moderately humid conditions in the latest Miocene (Colombero et al. 2017).

As recently summarized by Colombero et al. (2017), the Moncucco Torinese lissamphibian assemblage consists of eight or, perhaps, nine taxa. In addition to the Albanerpeton 


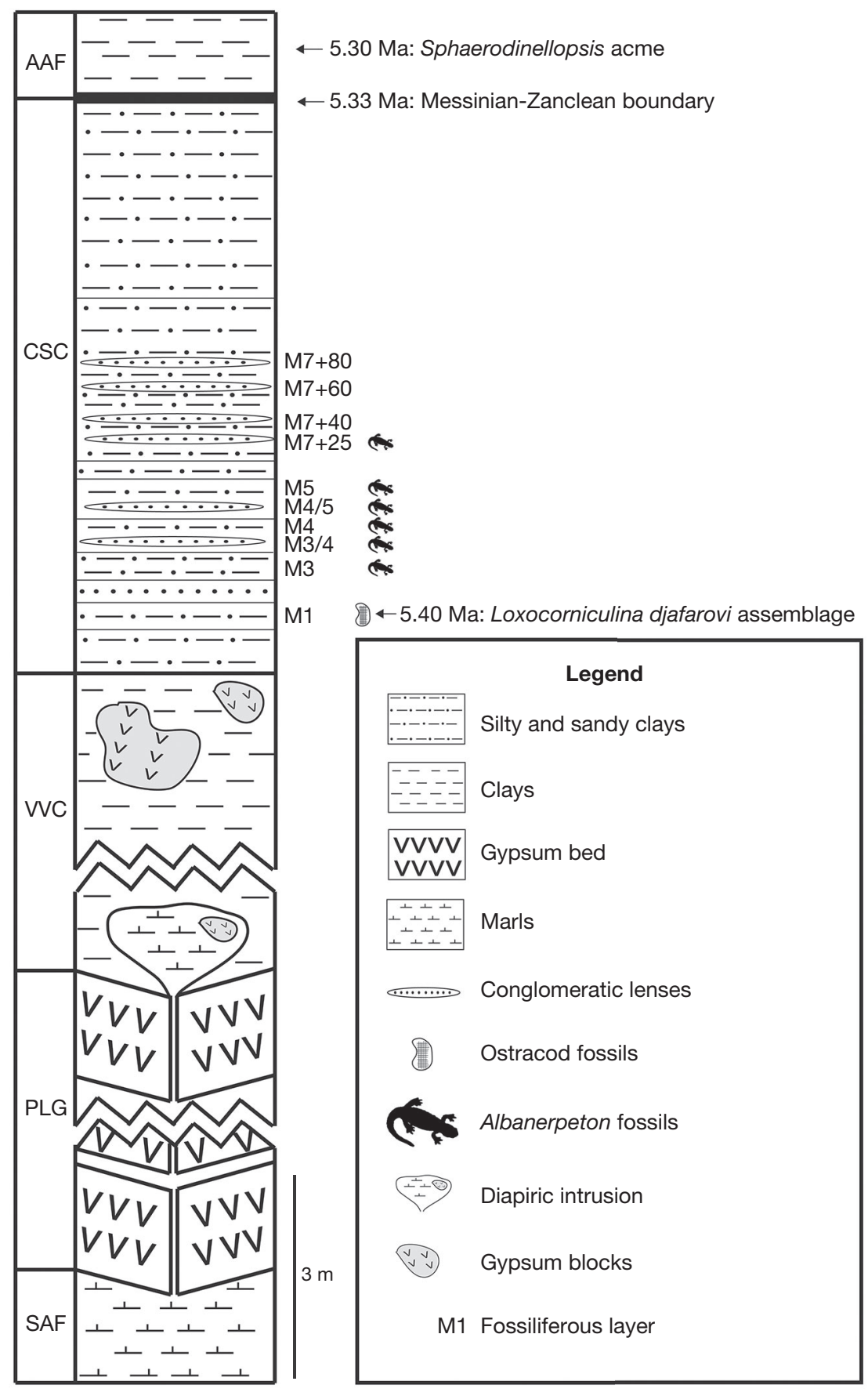

FIG. 2. - Stratigraphic section for the Miocene through Pliocene succession at Moncucco Torinese, Piedmont Basin, northwestern Italy. Arrows indicate the main biostratigraphic events and the Messinian-Zanclean (Miocene-Pliocene) boundary, all of which help constrain the age of the fossil-bearing interval within the Cassano Spinola Conglomerates. Numbered layers yielding isolated Albanerpeton Estes \& Hoffstetter, 1976 bones are indicated by Albanerpeton silhouettes to the right of the stratigraphic log. Modified from Colombero et al. (2017: fig. 2); for details see Dela Pierre et al. (2007, 2011). Abbreviations for rock units exposed within the section (left side of stratigraphic logs) (from top-to-bottom): AAF, Argille Azzurre Formation; CSC, Cassano Spinola Conglomerates; VVC, Valle Versa chaotic complex; PLG, Primary Lower Gypsum; SAF, Sant'Agata Fossili Marls.

pannonicum jaws and vertebrae described here, the locality also has yielded lesser numbers of the following lissamphibian fossils (see Colombero et al. 2017): vertebrae belonging to the salamandrid newts Chelotriton Pomel, 1853 and Lissotriton Bell, 1839; ilia belonging to a bufonid (Bufo viridis species group) and one or two ranids (Pelophylax sp. and an indeterminate taxon); ilia, scapulae, and vertebrae belonging to a hylid (Hyla arborea species group); angulosplenials belonging to an alytid (Latonia sp.); and a frontoparietal, vertebra, and ilia belonging to a pelobatid (Pelobates sp.). This is one of the most taxonomically diverse lissamphibian assemblages at the Miocene-Pliocene transition in Europe and the only one from that interval known to contain albanerpetontids (see Georgalis et al. 2019: table 1 and references therein). 


\section{MATERIAL AND METHODS}

The 55 albanerpetontid bones reported here are isolated, threedimensionally preserved jaws and vertebrae collected during excavations from 2007 to 2014 at Moncucco Torinese. All specimens are housed in the Museo di Geologia e Paleontologia at the Università degli Studi di Torino, Italy (MGPT-PU). As noted above, fossiliferous layers at Moncucco Torinese are numbered from bottom-to-top. During excavations, collections from the basal parts of layers M4 and M5 were labelled as, respectively, M3/4 and M4/5. Positions of fossils within the thick layer M7 are denoted by recording the distance in centimeters upwards from the base of the layer (e.g., M7+25). Most specimens were recovered by screen washing matrix from known stratigraphic layers; however, some specimens cannot reliably be assigned to a particular stratigraphic layer, because they either were collected in situ from an unrecorded interval or were surface collected. Our osteological terms and measurements for albanerpetontid elements follow Venczel \& Gardner (2005, and references therein) for jaws and Estes (1981) and McGowan (1996) for vertebrae. We follow Marjanovíc \& Laurin (2008) for spellings of Albanerpeton species names. We compared albanerpetontid specimens from Moncucco Torinese to the suite of albanerpetontid taxa and material listed by Venczel \& Gardner (2005).

\section{SYSTEMATIC PALAEONTOLOGY}

Subclass LISSAMPHIBIA Haeckel, 1866

Order ALLOCAUDATA Fox \& Naylor, 1982

Family AlBANERPETONTIDAE Fox \& Naylor, 1982

Genus Albanerpeton Estes \& Hoffstetter, 1976

Albanerpeton pannonicum Venczel \& Gardner, 2005 (Figs 3; 4)

MATERIAL. — Fifty-five isolated bones: Italy. Moncucco Torinese, Layer M3 ( $\mathrm{n}=3)$ : Premaxilla $(\mathrm{n}=1)$ : MGPT-PU 132112. Dentaries $(\mathrm{n}=2)$ : MGPT-PU 132630, 132631. — Layer M3/4 ( $\mathrm{n}=10)$ : Maxilla $(\mathrm{n}=1)$ : MGPT-PU 132274. Dentaries ( $\mathrm{n}=9)$ : MGPT-PU 132640-132647, 132652. — Layer M4 ( $n=1)$ : Sacral vertebra $(n=1)$ : MGPT-PU 132017. — Layer M4/5 ( $n=20)$ : Premaxillae $(n=3)$ : MGPT-PU 132001, 132002, 132232. Maxillae ( $\mathrm{n}=4)$ : MGPT-PU 132011, 132012, 132632, 132633. Dentaries ( $\mathrm{n}=11)$ : MGPT-PU 132005-132009, 132634-132639. Trunk vertebrae $(\mathrm{n}=2)$ : MGPT-PU 132015, 132016. — Layer M5 ( $\mathrm{n}=$ 2): Dentaries ( $\mathrm{n}=2$ ): MGPT-PU 132003, 132004. — Layer M7+25 $(\mathrm{n}=6)$ : Premaxillae $(\mathrm{n}=4)$ : MGPT-PU 132648-132651. Dentaries $(\mathrm{n}=$ 2): MGPT-PU 132653, 132654.

Collected in situ, from unrecorded layer(s) $(\mathrm{n}=4)$ : Premaxilla $(\mathrm{n}=$ 1): MGPT-PU 132165. Maxilla $(n=1)$ : MGPT-PU 132307. Dentaries $(\mathrm{n}=2)$ : MGPT-PU 132318, 132319.

Surface collected, from unknown layer $(s)(\mathrm{n}=9)$ : Maxillae $(\mathrm{n}=$ 2): MGPT-PU 132013, 132014. Dentaries ( $n=7)$ : MGPT-PU $132010,132655-132660$.

\section{DESCRIPTION OF MONCUCCO TORINESE}

\section{ALBANERPETONTID SPECIMENS}

Premaxillae (Fig. 3A-L)

Nine isolated premaxillae are available. The best-preserved specimen is MGPT-PU 132112 (Fig. 3A-C), an intact left premaxilla. Most other specimens (e.g., Fig. 3D-L) preserve an intact dorsally directed pars dorsalis, at least some portion of the lingually directed pars palatinum, and much of the ventrally directed pars dentalis and its tooth row. All premaxillae are relatively small (total intact heights range from 1.5-1.7 $\mathrm{mm}$ ), yet are comparatively robust in build when compared to similar sized premaxillae of other albanerpetontids (e.g., Gardner 1999b: text-fig. 2A-E). The medial edge is straight and bears prominent, vertical grooves and flanges for strong sutural contact or, perhaps, weak fusion (although no examples of fused premaxillae are present in our sample) in life between the paired premaxillae. In the eight specimens preserving an intact pars dorsalis, the process is moderately tall and broad, with the ratio of maximum height vs width across the suprapalatal pit ranging from 1.30-1.55 (i.e., relative height is "low" sensu Gardner 2002; Venczel \& Gardner 2005). The dorsal edge of the pars dorsalis is slightly swollen labiolingually and is roughened for abutting or weak sutural contact with the nasal. As seen in the five figured premaxillae, considerable variation is evident in the outline of the dorsal end of the pars dorsalis, the relative depth and width of the lateral dorsal notch along the upper portion of the pars dorsalis, and the outline of the laterally directed swelling immediately below the lateral dorsal notch (Fig. 3A, D, G, I, K). The uppermost portion of the pars dorsalis labially bears a low bony boss that is weakly ornamented with irregular-shaped, small pits and low ridges. The remainder of the premaxillary labial surface is relatively smooth, aside from small and scattered nutritive foramina. Midway across its lower half, the lingual surface of the pars dorsalis bears a suprapalatal pit that faces lingually, is moderately large and undivided, has an asymmetrically ovoid to subtriangular outline, and is bounded laterally by an obliquely oriented bony strut (Fig. 3C, F, H, J, L). Preserved intact on just one specimen, MGPT-PU 132112 (Fig. 3B, C), the pars palatinum is a shallow, bony shelf that medially bears a lingually projecting, triangular vomerine process and laterally is expanded into a maxillary process for contact with the maxilla. The central portion of the pars palatinum is pierced by a prominent palatal foramen that opens into the floor of the suprapalatal pit. The palatal foramen is subcircular and varies in size, with its diameter ranging from approximately the same as the diameter of shafts of medial teeth on the same specimen to twice the diameter of those shafts. The pars dentalis is relatively deep. Five premaxillae preserve an intact tooth row, consisting of either seven or eight tooth positions (two and three specimens, respectively). Teeth are typical for albanerpetontids in being highly pleurodont, non-pedicellate, and closely spaced in a comb-like arrangement, in having shafts that are deep, straight, cylindrical, and slightly mesiodistally compressed, and in bearing chisel-shaped crowns that are labiolingually compressed and mesiodistally tricuspid, with the median cusp most prominent. Some premaxillae have fully functional teeth occupying all loci (e.g., Fig. 3C, $\mathrm{J}$ ), whereas others have one or several empty tooth slots (e.g., Fig. 3F). One of the figured examples (Fig. 3L) exhibits a nearly functional replacement tooth in its fifth locus from the mesial (= medial) end. 

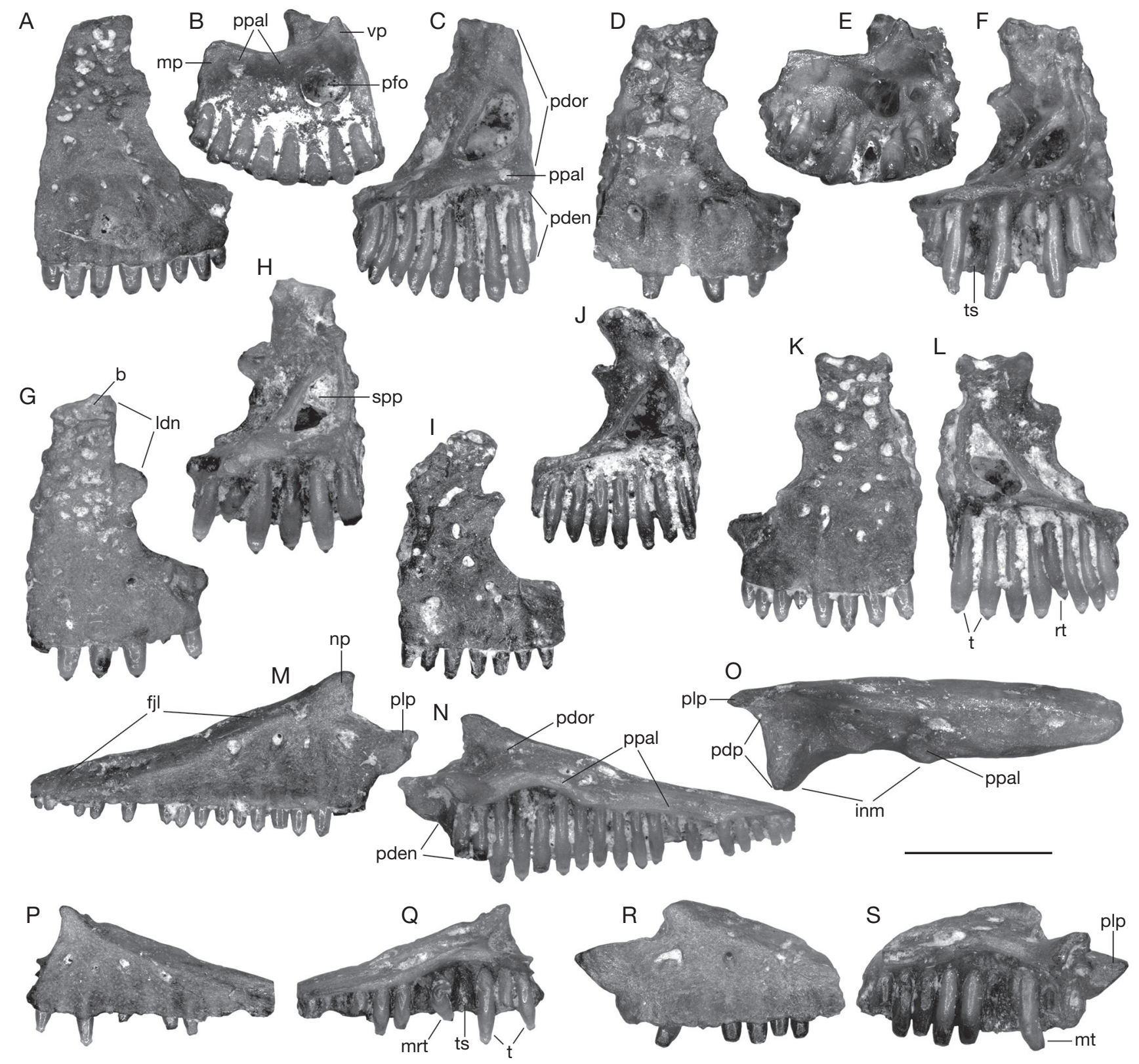

FIG. 3. - Isolated premaxillae (A-L) and maxillae (M-S) of Albanerpeton pannonicum Venczel \& Gardner, 2005 from the uppermost Miocene (Messinian) locality of Moncucco Torinese, Piedmont Basin, northwestern Italy: A-C, MGPT-PU 132112, complete left premaxilla, in labial (A), ventral (B), and lingual (C) views, from layer M3; D-F, MGPT-PU 132001, nearly complete left premaxilla, in labial (D), ventral (E), and lingual (F) views, from layer M4/5; G, H, MGPT-PU 132165, nearly complete left premaxilla, in labial (G) and lingual (H) views, from unrecorded layer; I, J, MGPT-PU 132232, nearly complete left premaxilla, in labial (I) and lingual (J) views, from layer M4/5; K, L, MGPT-PU 132648, nearly complete right premaxilla, in labial (K) and lingual (L) views, from layer M7+25; M-O, MGPTPU 132307, nearly complete right maxilla, in labial (M), lingual, (N), and dorsal (0) views, from unrecorded layer; P, Q, MGPT-PU 132012, left maxilla missing anterior and posterior ends, in labial (P) and lingual $(\mathbf{Q})$ views, from layer M4/5; R, S, MGPT-PU 132014, left maxilla preserving about anterior one-half of bone, in labial (R) and lingual (S) views, surface collected. Abbreviations: b, boss; fjl, flattened area for contact with jugal and lacrimal; inm, internal narial margin; Idn, lateral dorsal notch; mp, maxillary process; mt, misshaped functional tooth; mrt, misshaped replacement tooth; np, nasal process; pden, pars dentalis; pdor, pars dorsalis; pdp, premaxillary dorsal process; pfo, palatal foramen; plp, premaxillary lateral process; ppal, pars palatinum; rt, replacement tooth; spp, suprapalatal pit; $\mathbf{t}$, functional teeth; ts, tooth slot; vp, vomerine process. All images are photographs of undusted specimens. All specimens are depicted at same magnification. Scale bar: $1 \mathrm{~mm}$.

\section{Maxillae (Fig. 3M-S)}

The most nearly complete and informative of the eight maxillary specimens is MGPT-PU 132307 (Fig. 3M-O), a right maxilla missing only a small piece from the anteroventral portion of its premaxillary lateral process and the distal ends of five teeth. Considering the minor amount of breakage at its anterior end, the specimen's preserved maximum length of $2.7 \mathrm{~mm}$ likely reflects the true size of that maxilla. Although the other two figured specimens are less nearly complete, when intact those maxillae would have been slightly smaller (MGPT-PU 132012: Fig. 3P, Q) and larger (MGPT-PU 132014: Fig. 3R, S) in their maximum lengths compared to MGPT-PU 132307. As best shown by MGPT-PU 132307 and, to a lesser extent by MGPT-PU 
132012 , in overall form the maxilla is moderately elongate, low, and triangular in labial or lingual outline. The pars dorsalis increases in height anteriorly, culminating in the dorsally projecting, triangular nasal process having a leading edge that is either nearly vertical or shallowly concave in labial or lingual outline (cf., Fig. 3M vs Fig. 3P, R). The pars dorsalis extends forward below and past the level of the nasal process as a moderately elongate premaxillary lateral process that, in life, labially (= laterally) overlapped with a corresponding facet on the premaxilla (see Venczel \& Gardner 2005: text-fig. 1A). The intact premaxillary lateral process preserved on MGPT-PU 132014 (Fig. 3R, $S$ ) is bluntly pointed in labial or lingual outline. From the posterior base of the nasal process backwards to the posterior end of the bone, the dorsal surface of the pars facialis is slightly flattened where, in life, it was overlain by the jugal and lacrimal (see Venczel \& Gardner 2005: text-fig. 4). The labial surface of the maxilla is smooth, aside from a few small external nutritive foramina arranged in a loose row along about the anterior one-half of the bone. The lingual surface of the maxilla bears a lingually directed, shelf-like pars palatinum that is broadest anteriorly and narrows posteriorly (Fig. 3O). The anterior end of the pars palatinum is expanded into the premaxillary dorsal process that, in life, dorsally overlapped onto the similarly expanded lateral portion (= maxillary process) of the pars palatinum on the premaxilla. More posteriorly, the medial edge of the pars palatinum is indented by a shallow concavity forming the lateral margin of the internal narial opening and the dorsal surface of the shelf bears short ridges and a trough for contact, in life, with palatal bones. The pars dentalis is deepest anteriorly, becomes shallower posteriorly, and its ventral margin is essentially straight in labial or lingual outline. Starting at a point approximately below the leading edge of the nasal process (Fig. 3N, S), the maxillary tooth row extends backwards to the posterior end of the bone (Fig. $3 \mathrm{~N}$ ). The only maxilla with an intact tooth row, MGPT-PU 132307 (Fig. 3N), has 19 tooth positions comprised of 13 intact teeth, five broken tooth shafts, and one empty tooth slot. Teeth are similar in form, attachment, and arrangement to the premaxillary teeth. Maxillary teeth are weakly heterodont in size, being longest about one-third of the distance along the tooth row. MGPT-PU 132012 (Fig. 3Q) preserves a misshaped, slightly procurved replacement tooth in the fifth preserved locus from the mesial (= anterior) end, whereas MGPT-PU 132014 (Fig. 3S) preserves a similarly misshaped functional tooth in the second locus from the mesial end.

\section{Dentaries (Fig. 4A-M)}

None of the 35 dentaries is complete, but collectively they document much of the structure of this element. The most nearly complete specimen is MGPT-PU 132003 (Fig. 4A-C), a right dentary preserving about the anterior four-fifths of the bone, including the entire tooth-bearing region and the anterior part of the area for attachment of the post-dentary bones. As best shown by MGPT-PU 132003, the dentary is elongate and moderately deep along its length in labial or lingual view, and is broadly curved in dorsal or ventral view. In labial view (Fig. 4A, D, G, J, L), the dorsal edge of the tooth-bearing region is essentially horizontal. Behind the tooth row, the dorsal edge bears a low, almost indistinct, dorsally directed swelling and, more posteriorly, the dorsal edge descends shallowly above the area for attachment of the post-dentary bones. The labial surface of the bone is unornamented, although it is slightly roughened and, along the tooth-bearing portion, is perforated by a half dozen or more, moderate sized external nutritive foramina loosely arranged in either one or two horizontal rows (cf., Fig. $4 \mathrm{G}$ vs Fig. 4A, D). As seen in lingual and dorsal views (Fig. 4B, E, H and C, F. I, respectively), the symphyseal end of the dentary consists of an anteriorly swollen, flat, vertical face and, more posteriorly, bears either one or two short, medioposteriorly directed prongs that, in life, formed a mortise-in-tenon style inter-symphyseal joint. The toothbearing portion consists of a relatively tall dental parapet that becomes shallower posteriorly and a well-developed subdental shelf with a gutter-like dorsal surface. The subdental shelf becomes narrower and deeper posteriorly. Near the end of the tooth row, the subdental shelf is perforated by the large posterior opening for the Meckelian canal and, more posteriorly, in the area lingually (= medially) overlain in life by the post-dentary bones (see Venczel \& Gardner 2005: text-fig. 5A, D), the lingual surface of the dentary is shallowly concave and bears thin, posteriorly extending bony ridges. The few specimens preserving a complete or nearly complete tooth row (e.g., MGPT-PU 132003: Fig. 4A-C) indicate that 20-25 tooth positions were present. Teeth are similar in form, attachment, and arrangement to those on the upper jaws and, like on the maxilla, dentary teeth are weakly heterodont in size, with the longest teeth occurring about one-third of the distance along the tooth row. The anterior portion of a right dentary, MGPT-PU 132010 (Fig. 4G, H), is notable for having an anomalous, plate-like patch of bone developed on the underside of its symphyseal region.

\section{Vertebrae (Fig. 4N-U)}

Although incomplete and less distinctive than the abovedescribed jaws, albanerpetontid post-atlantal vertebrae can be recognized by a suite of features (Estes \& Hoffstetter 1976; Estes 1981; McGowan 1996; Wiechmann 2003; Venczel \& Gardner 2005; Sweetman \& Gardner 2013; Matsumoto \& Evans 2018), including: small size; centra amphicoelous, notochordal, external surfaces relatively smooth, and bearing donut-like ring of calcification around cotylar rims; no spinal foramina; and unicipital rib-bearers. Two trunk vertebrae and one sacral vertebra are available from Moncucco Torinese; here we figure the better preserved trunk vertebra (MGPT-PU 132015: Fig. 4N-P) and the sole sacral vertebra (MGPT-PU 132017: Fig. 4Q-U). All three specimens are tiny (maximum centra lengths $=1.2-1.4 \mathrm{~mm}$ ). Each consists of an intact centrum, the broken bases of the neural arch walls, and varying amounts of the transverse processes. Judging from the broken bases of the neural arch walls, the neural arches and 


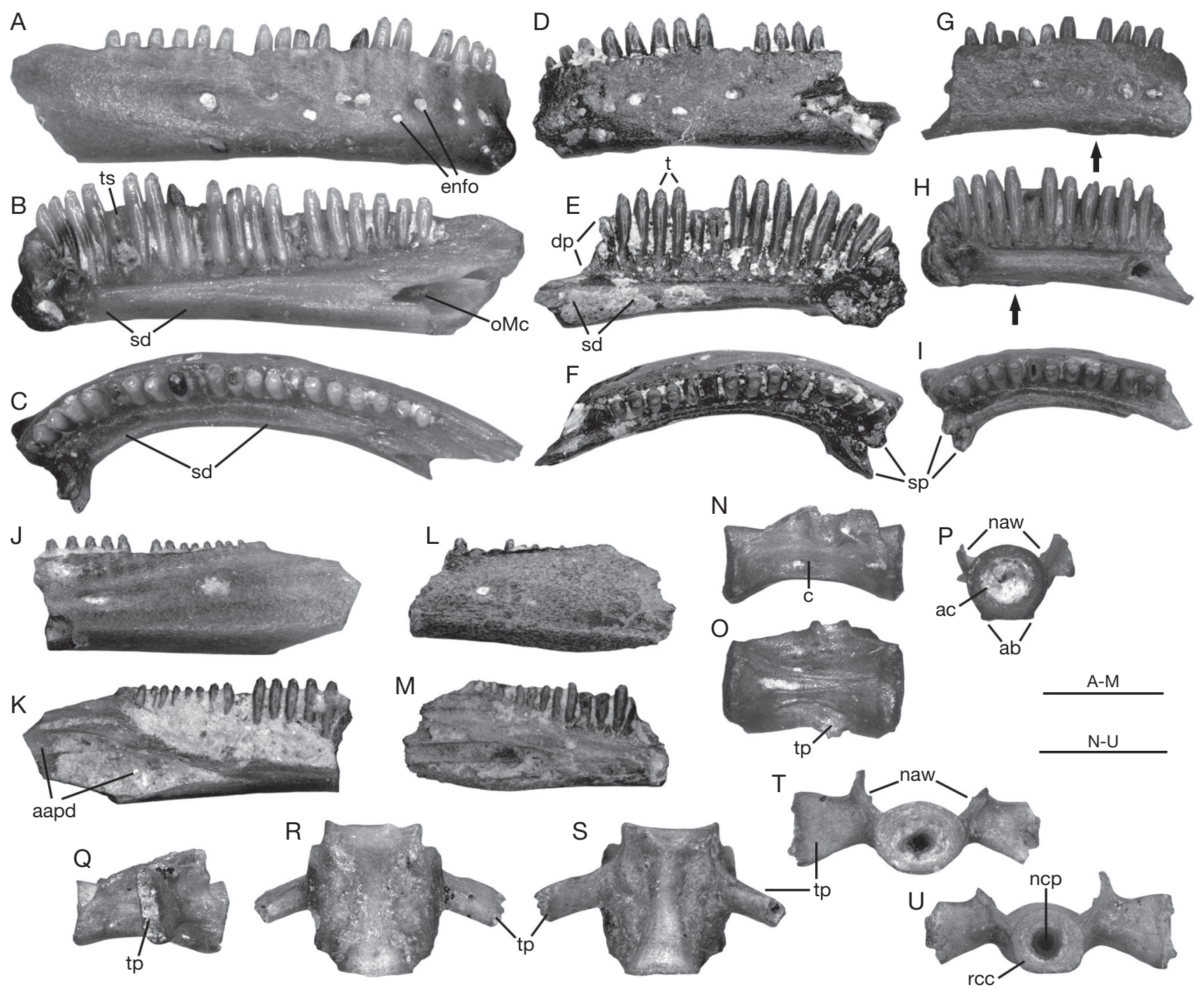

FIG. 4. - Isolated dentaries (A-M) and vertebrae (N-U) of Albanerpeton pannonicum Venczel \& Gardner, 2005 from the uppermost Miocene (Messinian) locality of Moncucco Torinese, Piedmont Basin, northwestern Italy: A-C, MGPT-PU 132003, right dentary preserving about anterior four-fifths of bone, including entire tooth-bearing region, in labial (A), lingual (B), and dorsal (C) views, from layer M5; D-F, MGPT-PU 132643, left dentary preserving about anterior one-half of bone, in labial (D), lingual (E), and dorsal (F) views, from layer M3/4; G-I, MGPT-PU 132010, right dentary preserving about anterior one-third of bone and exhibiting anomalous, plate-like bony growth (arrow) on ventral surface of symphyseal region, in labial (G), lingual (H), and dorsal (I) views, surface collected; J, K, MGPT-PU 132631 , left dentary preserving posterior portion of tooth-bearing region and adjacent part of area for attachment of post-dentary bones, in labial ( $\mathbf{J}$ ) and lingual (K) views, from layer M3; L, M, MGPT-PU 132638, left dentary preserving posterior portion of tooth-bearing region and adjacent part of area for attachment of post-dentary bones, in labial (L) and lingual (M) views, from layer M4/5; N-P, MGPT-PU 132015, trunk vertebra missing much of neural arch, in right lateral (N) view, in ventral (0) view with anterior end to right, and in anterior (P) view, from layer M4/5; Q-U, MGPT-PU 132017, sacral vertebra missing much of neural arch, in right lateral $(\mathbf{Q})$ view, in dorsal $(\mathbf{R})$ and ventral $(\mathbf{S})$ views, both with anterior end towards top of figure, and in anterior $(\mathbf{T})$ and posterior $(\mathbf{U})$ views, from layer M4. Abbreviations: aapd, area for attachment of post-dentary bones; ab, anterior basapophysis; ac, anterior cotyle; c, centrum; dp, dental parapet; enfo, external nutritive foramina; naw, broken base of neural arch wall; ncp, notochordal pit; oMc, opening for Meckelian canal; rcc, rim of calcified cartilage; sd, subdental shelf; sp, symphyseal prongs; t, functional teeth; tp, transverse process; ts, tooth slot. All images are photographs of undusted specimens. Dentaries (upper scale bar) are depicted at same magnification and vertebrae (lower scale bar) are depicted at same magnification. Scale bars: $1 \mathrm{~mm}$.

canals were broad. In each specimen, the centrum is deeply amphicoelous and perforated by a persistent or open notochord, the anterior and posterior cotyles are rimmed with a donut-like ring of calcified cartilage, and no spinal foramina or ventromedian keel are present. In both trunk vertebrae, the centrum is relatively elongate and somewhat hourglass-shaped (i.e., moderately constricted midway along its length), the anterior and posterior cotyles are subcircular in outline, and a faint ridge extends posteriorly and slightly laterally along either side of the ventral midline. On both trunk vertebrae, the broken bases of the transverse processes are positioned low on the broken neural arch wall, slightly forward of the anteroposterior midpoint of the centrum. Judging by their broken bases, the transverse processes were rod-shaped. Trunk vertebra MGPT-PU 132015 bears weakly-developed anterior basapophyses in the form of low, anteroposteriorly short knobs that barely extend forward beyond the anterior cotylar rim (Fig. 4N-P); the other trunk vertebra (MGPTPU 132016: unfigured) lacks anterior basapophyses. We identify MGPT-PU 132017 (Fig. 4Q-U) as a sacral vertebra 
because its centrum is relatively broad and anteroposteriorly short, not constricted, and slightly flattened dorsoventrally, it lacks basapophyses, and it bears deep and stout transverse processes that arise lower on the neural arch wall. Although the form of the transverse processes on MGPT-PU 132017 resembles those on anteriormost trunk vertebrae figured by Estes \& Hoffstetter (1976: fig. 2A, B, pl. VI, 12, 13) for Albanerpeton inexpectatum, the latter specimens differ from MGPT-PU 132017 in bearing both anterior and posterior basapophyses.

\section{DISCUSSION}

\section{TAXONOMIC IDENTIFICATION}

\section{OF THE MONCUCCO TORINESE SPECIMENS}

Specimens reported here from Moncucco Torinese exhibit a suite of features typical for albanerpetontid jaws and vertebrae (e.g., Estes \& Hoffstetter 1976; Fox \& Naylor 1982; Gardner 2000a, 2001, 2002; McGowan 1996, 2002; Wiechmann 2003; Venczel \& Gardner 2005; Sweetman \& Gardner 2013; Szentesi et al. 2013); especially notable are the distinctive non-pedicellate and chisel-like teeth on the jaws and the autapomorphic symphyseal prongs on the dentaries. Based on their restricted stratigraphic and geographic occurrence and because there is no evidence for multiple premaxillary, maxillary, or dentary morphs, we associate all albanerpetontid jaws and associated vertebrae from Moncucco Torinese within one species.

Jaws are considered useful for differentiating many albanerpetontid species (e.g., Estes \& Hoffstetter 1976; Fox \& Naylor 1982; Gardner 1999a, b, c, 2000a, b; Gardner et al. 2003; Venczel \& Gardner 2005; Sweetman \& Gardner 2013). Compared to currently recognized albanerpetontid species, the Moncucco Torinese jaws are most similar to those described for Albanerpeton pannonicum (Venczel \& Gardner 2005; Delfino \& Sala 2007; Szentesi et al. 2015) in the following combination of features: relatively small size; premaxilla relatively robust, with pars dorsalis relatively low, dorsal boss confined to upper one-third or less of pars dorsalis, labial ornament confined to dorsal boss and consists of irregular, small pits and low ridges, and suprapalatal pit faces lingually, positioned low within pars dorsalis, and moderately large and ovoid to subtriangular in outline; maxilla and dentary not ornamented labially, occlusal edges of tooth-bearing regions relatively straight in labial profile, and teeth weakly heterodont in size anteriorly. Two variable premaxillary features considered diagnostic for $A$. pannonicum (Venczel \& Gardner 2005) are invariant among the available premaxillae from Moncucco Torinese: premaxillae are consistently single (vs some weakly fused) and the suprapalatal pit is consistently single (vs subdivided in some specimens). Lack of variation in those features among the Moncucco Torinese premaxillae is likely due to the smaller sample size of nine premaxillae from that locality not capturing the fuller range of variability, compared to the larger sample of 45 premaxillae available from the lower Pliocene Csarnóta 2 type locality for $A$. pannonicum. We note that only unfused premaxillae with an undivided suprapalatal pit also occur in smaller samples of $A$. pannonicum premaxillae from the upper Pliocene Csarnóta 3 locality ( $\mathrm{n}=3$; Szentesi et al. 2015) and the Lower Pleistocene Rivoli Veronese locality $(\mathrm{n}=1$; Delfino \& Sala 2007). By contrast, other aspects of premaxillary variation previously reported for $A$. pannonicum (Venczel \& Gardner 2005; Delfino \& Sala 2007; Szentesi et al. 2015) are evident in the Moncucco Torinese sample, including: outline of the dorsal end of the pars dorsalis; relative depth and width of the lateral dorsal notch; size and form of the laterally directed swelling immediately below the lateral dorsal notch; shape of the suprapalatal pit; and relative size of the palatal foramen.

Albanerpeton inexpectatum is the only other albanerpetontid species currently recognized from the Cenozoic of Europe, so it is appropriate to compare its jaws with those from Moncucco Torinese. A. inexpectatum exhibits four jaw autapomorphies (Gardner 1999a, 2002) not seen in material from Moncucco Torinese or in any jaws previously reported for $A$. pannonicum (Venczel \& Gardner 2005; Delfino \& Sala 2007; Szentesi et al. 2015): premaxilla lacks dorsal boss (vs small boss present in A. pannonicum); premaxilla ornamented labially with raised pustules covering entire surface of pars dorsalis (vs ornament in A. pannonicum consists of irregular, small pits and low ridges confined to dorsal boss); larger sized maxillae and dentaries ornamented labially with low, irregular ridges (vs ornament absent in A. pannonicum); and dentary bears a prominent, dorsally projecting, triangular process immediately behind tooth row (vs prominent process absent in $A$. pannonicum).

In summary, based on similarities and differences listed above, we refer the albanerpetontid jaws from Moncucco Torinese to Albanerpeton pannonicum. Although albanerpetontid vertebrae are not known to be diagnostic to genus or species, we also refer the three vertebrae from Moncucco Torinese to $A$. pannonicum based on their association with jaws of that species.

\section{The European CENOZOIC ALBANERPETONTID RECORD}

Aside from small collections of undescribed albanerpetontid bones from the middle and late Paleocene of southern Alberta, Canada (e.g., Fox \& Naylor 1982; Gardner \& Böhme 2008; Gardner \& DeMar 2013), the Cenozoic record for albanerpetontids otherwise is limited to Europe. Isolated and rare articulated bones of the type genus Albanerpeton have been reported from over 40 localities of early Oligocene-Early Pleistocene age in Austria, Czech Republic, France, Germany, Hungary, Italy, and Serbia (Table 1). The Moncucco Torinese occurrence extends the temporal range for $A$. pannonicum from its previously known occurrences in the Early Pleistocene and Pliocene (Venczel \& Gardner 2005; Delfino \& Sala 2007; Szentesi et al. 2015) back into the latest Miocene (i.e., MN1713). This narrows the temporal gap between $A$. pannonicum and the other European congener, $A$. inexpectatum, the latter of which ranges from the late (but not latest) Miocene back to the early Oligocene (MN9-MP21). These two temporally separate congeners also have different geographic ranges: $A$. pannonicum is known only from a few localities in central Hungary and northern Italy, whereas $A$. inexpectatum has a 
TABLE 1. - Cenozoic occurrences of Albanerpetontidae in Europe. Data assembled from various sources, including the "fosFARbase" on-line database of Triassic-Neogene occurrences of lower tetrapods maintained by Böhme \& Ilg (2003) and the summary table of global albanerpetontid occurrences presented by Gardner \& Böhme (2008: table 12.2). Citations in "References" column are limited to publications in which albanerpetontids were first reported or otherwise documented in a significant manner. An asterisk (*) denotes publications in which specimens were described, figured, or both. For older Mesozoic occurrences for albanerpetontids in Europe, see summaries by Böhme \& Ilg (2003), Gardner \& Böhme (2008: table 12.2), Sweetman \& Gardner (2013: table 2), and Szentesi et al. (2013: table 1). Notes: (1), Age originally reported as late Pliocene (Gelasian, MN17: see Delfino \& Sala 2007). Subsequent lowering of the base of the Pleistocene to coincide with the base of the Gelasian (see Gibbard et al. 2010) means Rivoli Veronese is now considered Early Pleistocene in age; (2), Fissure fills near the villages of La Grive and Saint Alban are grouped together, because precise locality details are lacking for many of the Albanerpeton inexpectatum fossils from there; the listed fissures and quarries are known to have yielded bones of that species (Gardner 1999a). For more detailed accounts of the La Grive-Saint-Alban fissures, see Freudenthal \& Mein (1989) and Mein \& Ginsburg (2002); (3), Originally identified as "Albanerpeton cf. inexpectatum" (Đurić 2016); see "Discussion" for our comments on the specific identity of these Serbian fossils; (4), Identification follows accessed version of database maintained by Böhme \& Ilg (2003), rather than other cited publications; (5), MP zone reported by Wiechmann (2003: 151) is tentatively accepted here, even though each locality contains several fissure infills of different ages and Wiechmann (2003) did not identify which fissure infill(s) yielded albanerpetontid fossils; (6), Reported variously as "Herrlingen" (Wiechmann 2003: 151) or "Herrlingen 11" (Böhme \& llg 2003).

\begin{tabular}{|c|c|c|c|c|c|}
\hline Geological age & Locality & $\begin{array}{l}\text { Depositional } \\
\text { environment }\end{array}$ & Taxon & Material & References \\
\hline $\begin{array}{l}\text { Early Pleistocene, } \\
\text { Gelasian, MN17 (1) }\end{array}$ & Rivoli Veronese, Italy & karst & $\begin{array}{l}\text { Albanerpeton } \\
\text { pannonicum }\end{array}$ & $\begin{array}{l}\text { dentaries, maxillae, } \\
\text { premaxilla, frontal, } \\
\text { vertebra }\end{array}$ & $\begin{array}{l}\text { Delfino \& Sala }\left(2007^{\star}\right) \\
\quad \text { Villa et al. }(2018)\end{array}$ \\
\hline $\begin{array}{l}\text { late Pliocene, } \\
\text { Piacenzian, MN16A }\end{array}$ & Csarnóta 3, Hungary & karst & $\begin{array}{l}\text { Albanerpeton } \\
\text { pannonicum }\end{array}$ & $\begin{array}{l}\text { jaws, lacrimal, jugal, } \\
\text { frontals }\end{array}$ & Szentesi et al. (2015*) \\
\hline $\begin{array}{l}\text { early Pliocene, } \\
\text { Zanclean, MN15 }\end{array}$ & Csarnóta 2, Hungary & karst & $\begin{array}{l}\text { Albanerpeton } \\
\text { pannonicum }\end{array}$ & $\begin{array}{r}\text { abundant cranial and } \\
\text { post-cranial bones }\end{array}$ & $\begin{array}{l}\text { Venczel (2003); } \\
\text { Venczel \& Gardner } \\
\left(2005^{\star}\right) ; \text { Maddin } \\
\text { et al. (2013*) }\end{array}$ \\
\hline $\begin{array}{l}\text { late Miocene, } \\
\text { Messinian, MN13 }\end{array}$ & Moncucco Torinese, Italy & $\begin{array}{l}\text { mixed ephemeral } \\
\text { freshwater and } \\
\text { terrestrial }\end{array}$ & $\begin{array}{l}\text { Albanerpeton } \\
\text { pannonicum }\end{array}$ & $\begin{array}{l}\text { dentaries, maxillae, } \\
\text { premaxillae, } \\
\text { vertebrae }\end{array}$ & $\begin{array}{l}\text { Colombero et al. } \\
\text { (2014a); Colombero } \\
\text { et al. (2017); this } \\
\text { study* }^{*}\end{array}$ \\
\hline $\begin{array}{l}\text { late Miocene, } \\
\text { Tortonian, MN9 }\end{array}$ & Richardhof-Golfplatz, Austria, & lacustrine & $\begin{array}{l}\text { Albanerpeton } \\
\text { inexpectatum }\end{array}$ & unreported & $\begin{array}{l}\text { Harzhauser \& Tempfer } \\
\text { (2004) }\end{array}$ \\
\hline $\begin{array}{l}\text { late Miocene, } \\
\text { Tortonian, MN9 }\end{array}$ & Felsőtárkány 3/10, Hungary & fluvio-lacustrine & $\begin{array}{l}\text { Albanerpetontidae } \\
\text { indet. }\end{array}$ & dentary & Venczel \& Hír (2013) \\
\hline $\begin{array}{l}\text { middle Miocene, } \\
\text { Serravallian, MN7/8 } \\
\text { and ?MN6; possibly } \\
\text { also latest early } \\
\text { Miocene, Langhian, } \\
\text { ?MN5 }\end{array}$ & $\begin{array}{l}\text { La Grive-Saint-Alban quarries, } \\
\text { France (2): fissure M (MN7/8) } \\
\text { in Milliet Quarry, fissure L7 } \\
\text { (MN7/8) in Lechartier Quarry } \\
\text { and unrecorded fissures } \\
\text { (MN5-MN7/8) in Peyre and } \\
\text { Beau Quarry }\end{array}$ & karst & $\begin{array}{l}\text { Albanerpeton } \\
\text { inexpectatum }\end{array}$ & $\begin{array}{r}\text { abundant cranial and } \\
\text { post-cranial bones }\end{array}$ & $\begin{array}{l}\text { Estes \& Hoffstetter } \\
\begin{array}{l}\left(1976^{\star}\right) ; \text { Estes } \\
\left(1981^{\star}\right) ; \text { Gardner } \\
\left(1999 a^{\star}\right) ; \text { Maddin } \\
\text { et al. }\left(2013^{\star}\right)\end{array}\end{array}$ \\
\hline $\begin{array}{l}\text { middle Miocene, } \\
\text { Astracian, MN6 }\end{array}$ & Sansan, France & $\begin{array}{l}\text { marsh or } \\
\text { marginal } \\
\text { lacustrine }\end{array}$ & $\begin{array}{l}\text { Albanerpeton } \\
\text { inexpectatum }\end{array}$ & $\begin{array}{l}\text { dentaries, maxillae, } \\
\text { humerus }\end{array}$ & Rage \& Hossini $\left(2000^{\star}\right)$ \\
\hline $\begin{array}{l}\text { middle Miocene, } \\
\text { Langhian, MN5 }\end{array}$ & $\begin{array}{l}\text { Undorf bei Regensburg } \\
\text { (Bahnstrecke), Germany }\end{array}$ & floodplain & $\begin{array}{l}\text { Albanerpeton } \\
\text { inexpectatum }\end{array}$ & unreported & $\begin{array}{l}\text { Böhme (2003: } \\
\text { appendix 1) }\end{array}$ \\
\hline $\begin{array}{l}\text { middle Miocene, } \\
\text { Langhian, MN5 }\end{array}$ & $\begin{array}{l}\text { Gisseltshausen 1a and 1b, } \\
\text { Germany }\end{array}$ & floodplain & $\begin{array}{l}\text { Albanerpeton } \\
\text { inexpectatum }\end{array}$ & unreported & $\begin{array}{l}\text { Böhme (2003: } \\
\text { appendix 1) }\end{array}$ \\
\hline $\begin{array}{l}\text { middle Miocene, } \\
\text { Burdigalian, MN5 }\end{array}$ & $\begin{array}{l}\text { Sandelzhausen unterer } \\
\text { Geröllmergel C2 and C3/D1, } \\
\text { Germany }\end{array}$ & $\begin{array}{l}\text { riparian pool } \\
\text { and floodplain }\end{array}$ & $\begin{array}{l}\text { Albanerpeton } \\
\text { inexpectatum }\end{array}$ & jaws, vertebrae & $\begin{array}{l}\text { Böhme }(1999 ; 2003: \\
\text { appendix 1; 2010*) }\end{array}$ \\
\hline $\begin{array}{l}\text { early Miocene, } \\
\text { Burdigalian, MN5 }\end{array}$ & Maßendorf, Germany & floodplain & $\begin{array}{l}\text { Albanerpeton } \\
\text { inexpectatum }\end{array}$ & unreported & $\begin{array}{r}\text { Böhme (2003: } \\
\text { appendix 1) }\end{array}$ \\
\hline $\begin{array}{l}\text { early Miocene, } \\
\text { Burdigalian, MN5 }\end{array}$ & Eitensheim, Germany & floodplain & $\begin{array}{l}\text { Albanerpeton } \\
\text { inexpectatum }\end{array}$ & unreported & $\begin{array}{l}\text { Böhme (2003: } \\
\text { appendix 1) }\end{array}$ \\
\hline $\begin{array}{l}\text { early Miocene, } \\
\text { Burdigalian, MN5 }\end{array}$ & Arth 1, Germany & $\begin{array}{l}\text { riparian pool } \\
\text { and floodplain }\end{array}$ & $\begin{array}{l}\text { Albanerpeton } \\
\text { inexpectatum }\end{array}$ & unreported & $\begin{array}{l}\text { Böhme (2003: } \\
\text { appendix 1) }\end{array}$ \\
\hline $\begin{array}{l}\text { early Miocene, } \\
\text { Burdigalian, MN5 }\end{array}$ & Adelschlag, Germany & floodplain & $\begin{array}{l}\text { Albanerpeton } \\
\text { inexpectatum }\end{array}$ & premaxilla & $\begin{array}{l}\text { Böhme (2003: } \\
\text { appendix 1); } \\
\text { Reichenbacher et al. } \\
\text { (2004: table 2) }\end{array}$ \\
\hline $\begin{array}{l}\text { early Miocene, } \\
\text { Burdigalian, MN5 }\end{array}$ & Randecker Maar, Germany & lacustrine & $\begin{array}{l}\text { Albanerpeton } \\
\text { inexpectatum }\end{array}$ & $\begin{array}{r}\text { abundant cranial and } \\
\text { post-cranial bones }\end{array}$ & $\begin{array}{l}\text { Wiechmann (2001; } \\
\text { 2003*); Böhme } \\
\text { (2003: appendix 1); } \\
\text { Rasser et al. }\left(2013^{\star}\right)\end{array}$ \\
\hline $\begin{array}{l}\text { early Miocene, } \\
\text { Burdigalian, MN5 }\end{array}$ & $\begin{array}{l}\text { Puttenhausen } 1 \text { (= } \\
\text { Puttenhausen classic), } \\
\text { Germany }\end{array}$ & floodplain & $\begin{array}{l}\text { Albanerpeton } \\
\text { inexpectatum }\end{array}$ & unreported & $\begin{array}{l}\text { Böhme (2003: } \\
\text { appendix 1); Abdul } \\
\text { Aziz et al. (2010: } \\
\text { table 1) }\end{array}$ \\
\hline $\begin{array}{l}\text { early Miocene, } \\
\text { Burdigalian, MN5 }\end{array}$ & $\begin{array}{l}\text { Teiritzberg T2/3 and T2/6, } \\
\text { Austria }\end{array}$ & floodplain & Albanerpeton sp. & dentary & $\begin{array}{l}\text { Böhme (2002*; 2003: } \\
\text { appendix 1) }\end{array}$ \\
\hline
\end{tabular}


TABLE 1.- Continuation

\begin{tabular}{|c|c|c|c|c|c|}
\hline Geological age & Locality & $\begin{array}{l}\text { Depositional } \\
\text { environment }\end{array}$ & Taxon & Material & References \\
\hline $\begin{array}{l}\text { early Miocene, } \\
\text { Burdigalian, MN5 }\end{array}$ & Obergänserndorf 2, Austria & floodplain & Albanerpeton sp. & dentaries, maxilla & $\begin{array}{l}\text { Böhme }\left(2002^{*} ; 2003:\right. \\
\text { appendix 1) }\end{array}$ \\
\hline $\begin{array}{l}\text { early Miocene, } \\
\text { Burdigalian, MN4b }\end{array}$ & Oberdorf $\mathrm{O} 3$ and $\mathrm{O} 4$, Austria & $\begin{array}{l}\text { freshwater } \\
\text { swamp }\end{array}$ & $\begin{array}{l}\text { Albanerpeton } \\
\text { inexpectatum }\end{array}$ & $\begin{array}{l}\text { jaws, frontals, } \\
\text { parietals, ?lacrimal, } \\
\text { vertebrae }\end{array}$ & $\begin{array}{l}\text { Sanchíz }\left(1998^{\star}\right) \\
\text { Böhme }(2003: \\
\text { appendix 1) }\end{array}$ \\
\hline $\begin{array}{l}\text { early Miocene, } \\
\text { Burdigalian, MN4b }\end{array}$ & Erkertshofen 1, Germany & karst & $\begin{array}{l}\text { Albanerpeton } \\
\text { inexpectatum }\end{array}$ & unreported & $\begin{array}{l}\text { Böhme (2003: } \\
\text { appendix 1) }\end{array}$ \\
\hline $\begin{array}{l}\text { early Miocene, } \\
\text { Burdigalian, MN4b }\end{array}$ & $\begin{array}{l}\text { Petersbuch 4, 5, } 36 \text { (Coll } \\
\text { Rummel) and 38-Borden, } \\
\text { Germany }\end{array}$ & karst & $\begin{array}{l}\text { Albanerpeton } \\
\text { inexpectatum }\end{array}$ & unreported & $\begin{array}{l}\text { Böhme (2003: } \\
\text { appendix 1) }\end{array}$ \\
\hline $\begin{array}{l}\text { early Miocene, } \\
\text { Burdigalian, MN4a }\end{array}$ & $\begin{array}{l}\text { Petersbuch 2, 7, 8, and 28, } \\
\text { Germany }\end{array}$ & karst & $\begin{array}{l}\text { Albanerpeton } \\
\text { inexpectatum }\end{array}$ & $\begin{array}{l}\text { cranial and post- } \\
\text { cranial bones }\end{array}$ & $\begin{array}{l}\text { Böhme (2003: } \\
\text { appendix 1); } \\
\text { Wiechmann (2003*) }\end{array}$ \\
\hline $\begin{array}{l}\text { early Miocene, } \\
\text { Burdigalian, MN4 }\end{array}$ & Sibnica, Serbia & lacustrine & Albanerpeton sp. (3) & $\begin{array}{l}\text { premaxillae, dentaries, } \\
\text { frontals }\end{array}$ & , Đurić $\left(2016^{\star}\right)$ \\
\hline $\begin{array}{l}\text { early Miocene, } \\
\text { Burdigalian, MN3 }\end{array}$ & Stubersheim 3, Germany & karst & $\begin{array}{l}\text { Albanerpeton } \\
\text { inexpectatum }\end{array}$ & unreported & $\begin{array}{l}\text { Böhme (2003: } \\
\text { appendix 1) }\end{array}$ \\
\hline $\begin{array}{l}\text { early Miocene, } \\
\quad \text { Burdigalian, MN3 }\end{array}$ & Wintershof West, Germany & karst & $\begin{array}{l}\text { Albanerpeton } \\
\text { inexpectatum }\end{array}$ & unreported & $\begin{array}{l}\text { Böhme (2003: } \\
\text { appendix 1) }\end{array}$ \\
\hline $\begin{array}{l}\text { early Miocene, } \\
\text { Burdigalian, MN3 }\end{array}$ & Merkur-North, Czech Republic & & $\begin{array}{l}\text { Albanerpeton } \\
\text { inexpectatum }\end{array}$ & dentaries & $\begin{array}{l}\text { Böhme (2002; 2003: } \\
\text { appendix 1); Kvaček } \\
\text { et al. (2004: table 1); } \\
\text { Čerñanský }\left(2010^{*}\right)\end{array}$ \\
\hline $\begin{array}{l}\text { early Miocene, } \\
\text { Aquitanian, MN1 }\end{array}$ & Weißenburg 6, Germany & karst & $\begin{array}{l}\text { Albanerpeton } \\
\quad \text { inexpectatum (4) }\end{array}$ & unreported & $\begin{array}{l}\text { Böhme }(2003 \\
\quad \text { appendix 1) }\end{array}$ \\
\hline $\begin{array}{l}\text { late Oligocene, } \\
\text { Chattian, MP30 }\end{array}$ & Oberleichtersbach, Germany & lacustrine & $\begin{array}{l}\text { Albanerpeton } \\
\text { inexpectatum (4) }\end{array}$ & dentary & $\begin{array}{l}\text { Böhme, unpubl. obs. } \\
\text { (cited by Gardner \& } \\
\text { Böhme 2008: table } \\
\text { 12.2); Böhme (2008) }\end{array}$ \\
\hline $\begin{array}{l}\text { late Oligocene, } \\
\text { Chattian, MP28 (5) }\end{array}$ & Herrlingen (6), Germany & karst & $\begin{array}{l}\text { Albanerpetontidae } \\
\text { indet. }\end{array}$ & unreported & Wiechmann (2003) \\
\hline $\begin{array}{l}\text { early Oligocene, } \\
\text { Rupelian, MP23 }\end{array}$ & Ronheim 1, Germany & karst & Albanerpeton sp. & unreported & Böhme \& Ilg (2003) \\
\hline $\begin{array}{l}\text { early Oligocene, } \\
\quad \text { Rupelian, MP22-23 }\end{array}$ & Grafenmühle 11, Germany & karst & $\begin{array}{l}\text { Albanerpeton } \\
\quad \text { inexpectatum (4) }\end{array}$ & dentaries, vertebrae & $\begin{array}{l}\text { Böhme \& Ilg (2003); } \\
\text { Böhme (2008) }\end{array}$ \\
\hline $\begin{array}{l}\text { early Oligocene, } \\
\quad \text { Rupelian, MP22 (5) }\end{array}$ & $\begin{array}{l}\text { Ehrenstein (unspecified } \\
\text { fissure), Germany }\end{array}$ & karst & $\begin{array}{l}\text { Albanerpetontidae } \\
\text { indet. }\end{array}$ & unreported & Wiechmann (2003) \\
\hline $\begin{array}{l}\text { early Oligocene, } \\
\text { Rupelian, MP21 }\end{array}$ & Möhren 12, Germany & karst & $\begin{array}{l}\text { Albanerpeton } \\
\quad \text { inexpectatum (4) }\end{array}$ & unreported & $\begin{array}{l}\text { Böhme \& Ilg (2003); } \\
\text { Böhme (2008) }\end{array}$ \\
\hline
\end{tabular}

somewhat more northern range and is broadly distributed from western France eastwards through Germany and into Austria and the Czech Republic (Table 1).

Đurić (2016) recently reported "Albanerpeton cf. inexpectatum" on the basis of isolated premaxillae, dentaries, and frontals from the early Miocene (MN4) of Serbia. This occurrence is notable for being the most southeastern occurrence of a Cenozoic albanerpetontid in Europe and lies far outside of the known geographic range of $A$. inexpectatum. The identity of the Serbian fossils is unclear, because they are incomplete and were not well described or illustrated. Based on the published description and photographs (Đurić 2016: 58 and pl. 1a-d), the specimens clearly are albanerpetontid. The posteriorly incomplete frontals figured by Đurić (2016: pl. 1b) are reliably diagnostic for Albanerpeton in having a triangular outline (e.g., McGowan 1998; Gardner 2000a, 2002), and are typical for both $A$. inexpectatum and $A$. pannonicum in being shaped like an equilateral triangle in dorsal or ventral outline, in having ventrolateral crests that are relatively broad and with a concave ventral surface, and in bearing a narrow, spike-like internasal process (e.g., Gardner 1999a; Venczel \& Gardner 2005). As depicted in ventral view (Đurić 2016: pl. 1b1), the Serbian frontal bears a ridge along its ventral midline, between the ventrolateral crests; it is unclear whether this is the shallow and narrow ridge vairably seen at this position in some albanerpetontid frontals (e.g., Sweetman \& Gardner 2013: fig. 4F) or the more prominent, deeper, and broader "ventromedian keel" considered autapomorphic for $A$. pannonicum (e.g., Venczel \& Gardner 2005: text-fig. 6B, C, E). The figured Serbian dentary (Đurić 2016: pl. 1a) lacks labial ornament, but given its small size we would not expect ornament to be present if the dentary was from $A$. inexpectatum, because that feature appears only on larger dentaries and maxillae (Gardner 1999a). The two Serbian premaxillae, both figured in labial view (Đurić 2016: pl. 1c, d), appear to lack the pustulate ornament of $A$. inexpectatum, yet the presence or absence of a dorsal boss, the latter being diagnostic for $A$. inexpectatum, cannot be seen. Based on the two figured premaxillae, the Serbian material does not appear to belong to $A$. inexpectatum. The specimens may belong to 
A. pannonicum (if so, that would be a further temporal and geographic extension for the species, although the latter would be consistent with that species' more southern range) or to an unrecognized species of Albanerpeton. Further study of the Serbian material is warranted to clarify its specific identity.

Another unresolved aspect of the Cenozoic record for albanerpetonitids in Europe is why there are no Paleocene or Eocene records on the continent (e.g., Gardner \& Böhme 2008; Rage 2012)? Anurans and caudates have a modest record during those epochs in Europe (e.g., Estes et al. 1967; Rage 2003, 2012 and references therein; Smith et al. 2011), yet albanerpetontid remains have not been reported. This early-mid Paleogene gap is all the more puzzling, considering that albanerpetontid bones are ubiquitous components of older Late Cretaceous vertebrate assemblages across Europe (see Szentesi et al. 2013: table 1) and that diagnostic jaws and frontals of Albanerpeton are known from the latest Cretaceous of France and Romania (e.g., Grigorescu et al. 1999; Duffaud 2000; Folie \& Codrea 2005; Venczel et al. 2013).

\section{Acknowledgements}

We thank the crews who helped excavate, surface collect, and screen wash the Moncucco Torinese locality, the many colleagues who provided us with reprints and loans of comparative specimens, the Royal Tyrrell Museum Cooperating Society for funding MD's research trip to Drumheller in March 2015, the reviewers Annelise Folie (Royal Belgian Institute of Natural Sciences, Brussels) and Pavel Skutschas (St. Petersburg State University, Russia) for their constructive comments on the submitted version of our paper, and the editor of the thematic issue, Jean-Sébastien Steyer and the desk editor of the journal, Emmanuel Côtez (both Muséum national d'Histoire naturelle, Paris, France) for the invitation to contribute our paper to Jean-Claude Rage's memorial volume. Jean-Claude was a valued colleague and mentor who showed us many kindnesses and was unfailingly supportive of our respective research programs - he will be sorely missed. This is the publication number 356 of the Museo di Geologia e Paleontologia collections at the Università degli Studi di Torino.

\section{REFERENCES}

Abdul Aziz H., Böhme M., Rocholl A., Prieto J., Wijbrans J. R., BACHTADSE V. \& UlBIG A. 2010. — Integrated stratigraphy and ${ }^{40} \mathrm{Ar} /{ }^{39} \mathrm{Ar}$ chronology of the early to middle Miocene Upper Freshwater Molasse in western Bavaria (Germany). International Journal of Earth Sciences 99: 1859-1886. https://doi.org/10.1007/ s00531-009-0475-8

Angelone C., Colombero S., Esu D., Giuntelli P., Marcolini F., Pavia M., Trenkwalder S., Van den Hoek Ostende L. W., Zunino M. \& PAVIA G. 2011. — Moncucco Torinese, a new post-evaporitic Messinian fossiliferous site from Piedmont (NW Italy). Neues Jahrbuch für Geologie und Paläontologie, Abhandlungen 259: 89-104. https://doi.org/10.1127/0077-7749/2010/0108

BöHME M. 1999. - Die miozäne Fossil-Lagerstätte Sandelzhausen. 16. Fisch- und Herpetofauna - Erste Ergebnisse. Neues Jahrbuch für Geologie und Paläontologie, Abhandlungen 214: 487-495. https://doi.org/10.1127/njgpa/214/1999/487
BÖHME M. 2002. — Lower vertebrates (Teleostei, Amphibia, Sauria) from the Karpatian of the Korneuburg Basin - palaeoecological, environmental and palaeoclimatical implications. Beiträge zur Paläontologie 27: 339-353.

BöHme M. 2003. — The Miocene Climatic Optimum: evidence from ectothermic vertebrates of Central Europe. Palaeogeography, Palaeoclimatology, Palaeoecology 195: 389-401. https:// doi.org/10.1016/S0031-0182(03)00367-5

BÖHme M. 2008. - Ectothermic vertebrates (Teleostei, Allocaudata, Urodela, Anura, Testudines, Choristodera, Crocodylia, Squamata) from the Upper Oligocene of Oberleichtersbach (Northern Bavaria, Germany). Courier Forschungsinstitut Senckenberg 260: 161-183.

BÖHME M. 2010. — Ectothermic vertebrates (Actinopterygii, Allocaudata, Urodela, Anura, Crocodylia, Squamata) from the Miocene of Sandelzhausen (Germany, Bavaria) and their implications for environmental reconstruction and palaeoclimate. Paläontologische Zeitschrift 210: 3-41. https://doi.org/10.1007/ s12542-010-0050-4

BÖHME M. \& IlG A. 2003. - fosFARbase. Retrieved 30 January 2020 from http://www.wahre-staerke.com/

Brinkman D. B., Russell A. P., Eberth D. A. \& Peng J. 2004. Vertebrate palaeocommunities of the lower Judith River Group (Campanian) of southeastern Alberta, Canada, as interpreted from vertebrate microfossil assemblages. Palaeogeography, Palaeoclimatology, Palaeoecology 213: 295-313. https://doi.org/10.1016/ S0031-0182(04)00386-4

ČERÑANSKÝ A. 2010. — Albanerpetontid amphibian (Lissamphibia: Albanerpetontidae) from the Early Miocene of the locality Merkur-North (north-west of the Czech Republic): data and a description of a new material. Acta Geologica Slovaca 2: 113-116.

Colombero S., Alba D. M., Carnevale G., Delfino M., Giuntelli P., Mazza P., Palaia G., Pavia G. \& Pavia M. 2014a. Moncucco Torinese (Piedmont, NW Italy): an exceptionally rich latest Miocene vertebrate locality. Abstract Book and Field Trip Guide, European Association of Vertebrate Palaeontologists, XII Annual Meeting, Torino, Italy: 44.

Colombero S., Angelone C., Bonelli E., Carnevale G., Cavallo O., Delfino M., Giuntelli P., Mazza P., Pavia G., Pavia M. \& REPETTO G. 2014b. - The upper Messinian assemblages of fossil vertebrate remains of Verduno (NW Italy): Another brick for a latest Miocene bridge across the Mediterranean. Neues Jahrbuch für Geologie und Paläontologie, Abhandlungen 272: 287-324. https://doi.org/10.1127/0077-7749/2014/0408

Colombero S., Pavia G. \& Carnevale G. 2014c. - Messinian rodents from Moncucco Torinese, NW Italy: palaeobiodiversity and biochronology. Geodiversitas 36: 421-475. https://doi. org/10.5252/g2014n3a4

Colombero S., Pavia M. \& Carnevale G. 2015. — Old World porcupine (Rodentia, Hystricidae) remains from the late Messinian of Piedmont, NW Italy. Rivista Italiana di Paleontologia e Stratigrafia 121: 243-253.

Colombero S., Alba D. M., D’Amico C., Delfino M., Esu D., Giuntelli P., Harzhauser M., Mazza P. P. A., Mosca M., Neubauer T. A., Pavia G., Pavia M., Villa A. \& CarNEVALE G. 2017. — Late Messinian mollusks and vertebrates from Moncucco Torinese, north-western Italy. Paleoecological and paleoclimatological implications. Palaeontologia Electronica 20.1.10A: 1-66. https://doi.org/10.26879/658

Costa O. G. 1864. - Paleontologia del Regno di Napoli. Atti dell Accademia Pontaniana, Naples 8: 1-198, pls 1-16.

Daza J. D., Stanley E. L., Bolet A., Bauer A. M., Arias J. S., Čerñanský A., BevitT J. J., Wagner P. \& Evans S. E. 2020. - Enigmatic amphibians in mid-Cretaceous amber were chameleon-like ballistic feeders. Science 370: 687-691. https:// doi.org/10.1126/science.abb6005

Dela Pierre F., Festa A. \& Irace A. 2007. — Interaction of tectonic, sedimentary and diapiric processes in the origin of chaotic 
sediments: an example from the Messinian of the Torino Hills (Tertiary Piedmont Basin, northwestern Italy). Geological Society of America Bulletin 119: 1107-1119. https://doi.org/10.1130/ B26072.1

Dela Pierre F., Bernardi E., Cavagna S., Clari P., Gennari R., Irace A., Lozar F., Lugli S., Manzi V., Natalicchio M., Roveri M. \& ViolanTi D. 2011. — The record of the Messinian salinity crisis in the Tertiary Piedmont Basin (NW Italy): the Alba section revisited. Palaeogeography, Palaeoclimatology, Palaeoecology 310: 238-255. https://doi.org/10.1016/j.palaeo.2011.07.017

Delfino M. \& SAla B. 2007. — Late Pliocene Albanerpetontidae (Lissamphibia) from Italy. Journal of Vertebrate Paleontology 27: 716-719. https://doi.org/cqs627

DUFFAUD S. 2000. — Les faunes d'amphibiens du Crétacésupérieur à l'Oligocène inférieur en Europe: paléobiodiversité, évolution, mise en place. $\mathrm{PhD}$ dissertation, Muséum national d'Histoire Naturelle, Paris, France, $221 \mathrm{p}$.

ĐuRIĆ D. 2016. — The early Miocene herpetofauna (Amphibia and Squamata) from Sibnica, Serbia, in MARKović Z. \& MiLIVOJEVIĆ M. (eds), Life on the shore - geological and paleontological research in the Neogene of Sibnica and vicinity (Levač basin, Central Serbia). Part 1. Special Issue of the Natural History Museum in Belgrade: 57-61.

Estes R. 1981. - Gymnophiona, Caudata, in Wellnhofer P. (ed.), Encyclopedia of Paleoherpetology. Part 2. Gustav Fischer Verlag, Stuttgart, $115 \mathrm{p}$.

Estes R. \& HoffstetTeR R. 1976. — Les Urodèles du Miocène de La Grive-Saint-Alban (Isère, France). Bulletin du Muséum national d'Histoire naturelle, 3e Série, Sciences de la Terre 57 (398): 297-343. https://www.biodiversitylibrary.org/page/55505209

Estes R., Hecht M. \& Hoffstetter R. 1967. — Paleocene amphibians from Cernay, France. American Museum Novitates 2295: 1-25. http://hdl.handle.net/2246/3086

Evans S. E. \& MATSUMOTO R. 2018. - The history of albanerpetontid amphibians in Asia, in MARTIN T., SCHELLHORN R. \& Scultz J. A. (eds.). Abstracts, 13th Symposium on Mesozoic Terrestrial Ecosystems and Biota, Bonn, Germany. Terra Nostra 2018 (1): 23-24. https://doi.org/10.23689/fidgeo-2907

Evans S. E. \& Milner A. R. 1994. — Middle Jurassic microvertebrate assemblages from the British Isles, in FrASER N. C. \& SuEs H.-D. (eds), In the Shadow of the Dinosaurs: Early Mesozoic Tetrapods. Cambridge University Press, New York: 303-321.

Folie A. \& Codrea V. 2005. - New lissamphibians and squamates from the Maastrichtian of Hațeg Basin, Romania. Acta Palaeontologica Polonica 50: 57-71.

FOX R. C. \& NAYLOR B. G. 1982. - A reconsideration of the relationships of the fossil amphibian Albanerpeton. Canadian Journal of Earth Sciences 19: 118-128. https://doi.org/10.1139/e82-009

Freudenthal M. \& MeIN P. 1989. - Description of Fahlbuschia (Cricetidae) from various fissure fillings near La Give-St. Alban (Isère, France). Scripta Geologica 89: 1-11.

GARDNER J. D. 1999a. - Redescription of the geologically youngest albanerpetontid (?Lissamphibia): Albanerpeton inexpectatum Estes and Hoffstetter, 1976, from the Miocene of France. Annales de Paléontologie 85: 57-84. https://doi.org/10.1016/S07533969(99)80008-1

GARDNER J. D. 1999b. - The amphibian Albanerpeton arthridion and the Aptian-Albian biogeography of albanerpetontids. Palaeontology 42: 529-544. https://doi.org/10.1111/1475-4983.00083

GARDNER J. D. 1999c. - New albanerpetontid amphibians from the Albian to Coniacian of Utah, USA - bridging the gap. Journal of Vertebrate Paleontology 19: 632-638. https://doi.org/10.1080/ 02724634.1999 .10011177

GARDNER J. D. 2000a. - Revised taxonomy of albanerpetontid amphibians. Acta Palaeontologica Polonica 45: 55-70.

GARDNER J. D. 2000b. - Albanerpetontid amphibians from the Upper Cretaceous (Campanian and Maastrichtian) of North America. Geodiversitas 22 (3): 349-388.
GARDNER J. D. 2001. - Monophyly and the affinities of albanerpetontid amphibians (Temnospondyli; Lissamphibia). Zoological Journal of the Linnean Society 131: 309-352. https://doi. org/10.1111/j.1096-3642.2001.tb02240.x

GARDNER J. D. 2002. - Monophyly and intra-generic relationships of Albanerpeton (Lissamphibia; Albanerpetontidae). Journal of Vertebrate Paleontology 22: 12-22. https://doi.org/bbvjjv

GARDNER J. D. \& BÖHME M. 2008. - Review of the Albanerpetontidae (Lissamphibia), with comments on the paleoecological preferences of European Tertiary albanerpetontids, in SANKEY J. T. \& BASZIO S. (eds), Vertebrate Microfossil Assemblages: Their Role in Paleoecology and Paleobiogeography. Indiana University Press, Bloomington: 178-218.

Gardner J. D. \& DeMar D. G. JR. 2013. — Mesozoic and Paleocene lissamphibian assemblages of North America: a comprehensive review. Palaeobiodiversity and Palaeoenvironments 93: 459-515. https://doi.org/10.1007/s12549-013-0130-z

GARDNER J. D. \& RAGE J.-C. 2016. — The fossil record of lissamphibians from Africa, Madagascar, and the Arabian Plate. Palaeobiodiversity and Palaeoenvironments 96: 169-220. https://doi. org/10.1007/s12549-015-0221-0

Gardner J. D., Evans S. E. \& Sigogneau-Russell D. 2003. New albanerpetontid amphibians from the Early Cretaceous of Morocco and Middle Jurassic of England. Acta Palaeontologica Polonica 48: 301-319.

Georgalis G. L., Villa A., Ivanov M., Vasilyan D. \& Delfino M. 2019. - Fossil amphibians and reptiles from the Neogene locality of Maramena (Greece), the most diverse European herpetofauna at the Miocene/Pliocene transition boundary. Palaeontologia Electronica 22.3.68: 1-99.

Gibbard P. L., Head M. J., Walker M. J. C. \& The SubCommisSION ON QUATERNARY STRATIGRAPHY. 2010. — Formal ratification of the Quaternary System/Period and the Pleistocene Series/ Epoch with a base at 2.58 Ma. Journal of Quaternary Science 25: 96-102. https://doi.org/10.1002/jqs.1338

Grigorescu D., VenCZel M., Csiki Z. \& Limberea, R. 1999. New latest Cretaceous microvertebrate fossil assemblages from the Hațeg Basin (Romania). Geologie en Mijnbouw 78: 301-314. https://doi.org/10.1023/A:1003890913328

Grossi F., Gliozzi E. \& Cosentino D. 2011. - Paratethyan ostracod immigrants mark the biostratigraphy of the Messinian Salinity Crisis. Joannea, Geologie und Paläontologie 11: 66-68.

HAECKEL E. 1866. - Generelle Morphologie der Organismen: allgemeine Grundzüge der organischen Formen-Wissenschaft, mechanisch begründet durch die von Charles Darwin reformirte Descendenz-Theorie. Vol. 2. Georg Reimer, Berlin, 462 p. https://doi.org/10.5962/bhl.title.3953

Harzhauser M. \& Tempfer P. M. 2004. - Late Pannonian wetland ecology of the Vienna Basin based on molluscs and lower vertebrate assemblages (Late Miocene, MN9, Austria). Courier Forschungsinstitut Senckenberg 246: 55-68.

Harzhauser M., Neubauer T. A., Georgopoulou E., Esu D., D’Amico C., Pavia G., Giuntelli P. \& Carnevale G. 2015. Late Messinian continental and Lago-Mare gastropods from the Tertiary Piedmont Basin, NW Italy. Bollettino della Società Paleontologica Italiana 54: 1-53.

KvačEK Z., BÖHme M., DvořáK Z., KonZalová M., MaCH K., Proko, J. \& RajChl M. 2004. — Early Miocene freshwater and swamp ecosystems of the Most Basin (northern Bohemia) with particular reference to the Bílina Mine section. Journal of the Czech Geological Society 49: 1-40.

Lozar F., Clari P., Pierre F. D., Natalicchio M., Bernardi E., Violanti D., Costa E. \& Giardino M. 2015. - Virtual tour of past environmental and climate change: the Messinian succession of the Tertiary Piedmont Basin (Italy). Geoheritage 7: 47-56. https://doi.org/10.1007/s12371-014-0098-8

Maddin H. C., Venczel M., Gardner J. D. \& Rage J.-C. 2013. - Micro-computed tomography study of a three-dimensionally preserved neurocranium of Albanerpeton (Lissamphibia, 
Albanerpetontidae) from the Pliocene of Hungary. Journal of Vertebrate Paleontology 33: 568-587. https://doi.org/10.1080/0 2724634.2013.722899

Marjanovíc D. \& LAURin M. 2008. - A reevaluation of the evidence supporting an unorthodox hypothesis on the origin of extant amphibians. Contributions to Zoology 77: 149-199. https:// doi.org/10.1163/18759866-07703002

Matsumoto R. \& Evans S. E. 2018. - The first record of albanerpetontid amphibians (Amphibia: Albanerpetontidae) from East Asia. PLoS ONE 13(1): e0189767. https://doi.org/10.1371/ journal.pone.0189767

MCGOWAN G. J. 1996. — Albanerpetontid amphibians from the Jurassic (Bathonian) of southern England, in Morales M. (ed.), The continental Jurassic. Museum of Northern Arizona Bulletin 60: 227-234.

MCGOWAN G. J. 1998. - Frontals as diagnostic indicators in fossil albanerpetontid amphibians. Bulletin of the National Science Museum, Series C (Geology \& Paleontology) 24: 185-194.

MCGOWAN G. J. 2002. - Albanerpetontid amphibians from the Lower Cretaceous of Spain and Italy: a description and reconsideration of their systematics. Zoological Journal of the Linnean Society 135: 1-32. https://doi.org/10.1046/j.1096-3642.2002.00013.x

McGowan G. J. \& ENSOM P. C. 1997. — Albanerpetontid amphibians from the Lower Cretaceous of the Isle of Purbeck, Dorset. Proceedings of the Dorset Natural History and Archaeological Society 118: 113-117.

McGowan G. J. \& Evans S. E. 1995. — Albanerpetontid amphibians from the Cretaceous of Spain. Nature 373: 143-145. https:// doi.org/10.1038/373143a0

Mein P. \& Ginsburg L. 2002. - Sur l'âge relatif des différents dépôts karstiques miocènes de la Grive-Saint-Alban (Isère). Cabier scientifiques, Muséum d'Histoire naturelle de Lyon 2: 7-47.

OgG J. G., OgG G. M. \& Gradstein F. M. 2016. - A Concise Geologic Time Scale 2016. Elsevier, Amsterdam, 234 p.

RaGe J.-C. 2003. — Oldest Bufonidae (Amphibia, Anura) from the Old World: a bufonid from the Paleocene of France. Journal of Vertebrate Paleontology 23: 462-463. https://doi.org/drdzwp

RAGE J.-C. 2012. - Amphibians and squamates in the Eocene of Europe: what do they tell us? Palaeobiodiversity and Palaeoenvironments 92: 445-457. https://doi.org/10.1007/s12549-012-0087-3

Rage J.-C. \& Hossini S. 2000. — Les Amphibiens du Miocène moyen de Sansan, in GinSBURG L. (ed.), La faune miocène de Sansan et son environnement. Muséum national d'Histoire naturelle, Paris: 177-217 (Mémoires du Muséum national d'Histoire naturelle; 183).

Rasser M. W., Bechly G., Böttcher R., Ebner M., Heizmann E. P. J., HöltKe O., JoAChim C., Kern A. K., Kovar-Eder J., Nebelsick J. H., Roth-NebelSick A., SCHOCH R. R., SCHWEIGERT G. \& ZiEGLER R. 2013. - The Randeck Maar: palaeoenvironment and habitat differentiation of a Miocene lacustrine system. Palaeogeography, Palaeoclimatology, Palaeoecology 392: 426-453. https://doi.org/10.1016/j.palaeo.2013.09.025

Reichenbacher B., Böhme M., Heissig K., Prieto J. \& Kossler A. 2004. - New approach to assess biostratigraphy, palaeoecology and past climate in the South German Molasse Basin during the Early Miocene (Ottnangian, Karpatian). Courier Forschungsinstitut Senckenberg 249: 71-81.
SANCHíz B. 1998. — Vertebrates from the Early Miocene lignite deposits of the opencast mine Oberdorf (Western Styrian Basin, Austria): 2. Amphibia. Annalen des Naturhistorischen Museums Wien 99A: 13-29.

SKUTSCHAS P. P. 2007. - New specimens of albanerpetontid amphibians from the Upper Cretaceous of Uzbekistan. Acta Palaeontologica Polonica 52: 819-821.

Smith T., Dipuis C., Folie A., Quesnel F., Storme J.-Y., Lacumin P., Riveline J., MisSiaEn P., LADEVĖZE S. \& TANS J. 2011. — A new terrestrial vertebrate site just after the Paleocene-Eocene boundary in the Mortemer Formation of Upper Normandy, France. Comptes Rendus Palevol 10: 11-20. https://doi.org/10.1016/j.crpv.2010.11.004

SwEETMAN S. C. \& GARDNER J. D. 2013. - A new albanerpetontid amphibian from the Barremian (Early Cretaceous) Wessex Formation of the Isle of Wight, southern England. Acta Paleontologica Polonica 58: 295-324. https://doi.org/10.4202/app.2011.0109

Szentesi Z., Gardner J. D. \& VencZel M. 2013. - Albanerpetontid amphibians from the Late Cretaceous (Santonian) of Iharkút, Hungary, with remarks on regional differences in Late Cretaceous Laurasian amphibian assemblages. Canadian Journal of Earth Sciences 50: 268-281. https://doi.org/10.1139/e2012-024

SZENTESI Z., PAZONYI P. \& MÉSZÁROS L. 2015. - Albanerpetontidae from the late Pliocene (MN 16A) Csarnóta 3 locality (Villány Hills, South Hungary) in the collection of the Hungarian Natural History Museum. Fragmenta Palaeontologica Hungarica 32: 49-66. https://doi.org/10.17111/FragmPalHung.2015.32.49

VENCZEL M. 2003. — Late Neogene and Quaternary extinction of lower tetrapods in the Carpathian Basin, in European Association of Vertebrate Palaeontologists, $1^{\text {st }}$ Meeting, Basel, Switzerland, Abstracts with Program: 52.

VENCZEL M. \& GARDNER J. D. 2005. - The geologically youngest albanerpetontid amphibian, from the lower Pliocene of Hungary. Palaeontology 48: 1273-1300. https://doi.org/10.1111/j.14754983.2005.00512.x

VENCZEL M. \& HíR J. 2013. - Amphibians and squamates from the Miocene of Felsőtárkány Basin, N-Hungary. Palaeontographica Abteilung A, 300 (1-6): 117-158. https://doi.org/10.1127/ pala/300/2013/117

VencZel M., Vasile Ş., AleXandru A., \& CSIKI-SaVA Z. 2013. Additional albanerpetontid remains from the Maastrichtian of Hațeg Basin (Romania), in ȚABĂRĂ D. (ed.), Ninth Romanian Symposium on Paleontology, Iași, Romania, Abstract book: 92-93.

Villa A., Blain H.-A. \& Delfino M. 2018. - The Early Pleistocene herpetofauna of Rivoli Veronese (Northern Italy) as an evidence for humid and forested glacial phases in the Gelasian of Southern Alps. Palaeogeography, Palaeoclimatology, Palaeoecology 490: 393-403. https://doi.org/10.1016/j.palaeo.2017.11.016

WieCHMANN M. F. 2001. - Albanerpetontids from the Randeck Maar (lower/middle Miocene, southern Germany). Abstracts of papers, Society of Vertebrate Paleontology, 61st Annual Meeting, Bozeman, Montana, USA. Journal of Vertebrate Paleontology 21 (supplement to no. 3): 114A. https://www.jstor.org/stable/20061998

WIECHMANN M. F. 2003. - Albanerpetontidae (Lissamphibia) aus dem Mesozoikum der Iberischen Halbinsel und dem Neogen von Süddeutschland. PhD dissertation, Institut für Geologische Wissenschaften - Fachrichtung Paläontologie der Freien Universität Berlin, 179 p. 